\title{
Türkiye'de Engelli Bireyler ve Seçimlere Katılım
}

\author{
Betül AKYOL*, Ender AKYOL ${ }^{* *}$
}

Öz

$\mathrm{Bu}$ çalışmanın amacı, engelli bireylerin seçimlere katılım sürecinde ve oy kullanma sırasında karşılaștıkları sorunları tespit etmek, bu sorunları gidermek için çeşitli ülkelerdeki alternatif uygulamaları ortaya koymak ve ülkemizde uygulanmaya yeni başlayan engelli bireylere dönük uygulamaları değerlendirmektir. $\mathrm{Bu}$ amaç doğrultusunda ilk olarak Türkiye'de seçimlerin yasal ve kurumsal çerçevesi engelli bireyler açısından incelenmiş, Yüksek Seçim Kurulu (YSK) tarafından ön görülen oy kullanma yöntemleri gözden geçirilmiştir. Çalışmada ikinci olarak Malatya'da yaşayan seçme ve seçilme haklarına sahip, kısıtlı olmayan, yalnızca bedensel ve görme engelli bireylerin seçimlerde oy kullanma süreçleri ve deneyimlerini belirleyebilmek amaciyla yüz yüze derinlemesine görüşme gerçekleştirilmiştir. Görüşmelerden elde edilen veriler Birleşmiş Milletler Engellilerin Haklarına İlişkin Sözleşmede dikkat çekilen "tesisler", "seçim materyalleri" ve "seçim usulleri"nden oluşan üç eksen üzerine oturtularak analiz edilmiştir.

Anahtar Kelimeler: Engelli bireyler, Engelli hakları, Siyasal katılım, Seçimler, Oy Kullanma.

\section{Disabled People and Electoral Participation in Turkey}

\section{Abstract}

The aim of this study was to identify the problems that disabled people encounter during election process and voting, to show alternative practices in various countries in order to solve these problems, and to evaluate applications for newly started disabled people in country. For this purpose firstly the legal and institutional framework were examined for elections in terms of disabled individuals in Turkey, the Supreme Election Council (YSK) envisaged by voting methods have been revised.

Özgün Araștırma Makalesi (Original Research Article)

Geliş/Received: 19.09 .2018

Kabul/Accepted: 25.03 .2019

DOI: http://dx.doi.org/10.17336/igusbd.458496

* Dr. Öğr. Üyesi, İnönü Üniversitesi, Spor Bilimleri Fakültesi, Engellilerde Egzersiz ve Spor Eğitimi Bölümü, Malatya, Türkiye, E-posta: betul.akyol@inonu.edu.tr ORCID ID https://orcid.org/00000002-3836-1317

${ }^{* *}$ Dr. Öğr. Üyesi, İnönü Üniversitesi, İỉBF Siyaset Bilimi ve Kamu Yönetimi Bölümü, Malatya, Türkiye, E-posta: ender.akyol@inonu.edu.tr ORCID ID https://orcid.org/0000-0003-4715-0017 
Secondly, in the study, in-depth interviews were held with the aim of determining the voting processes and experiences of electors with physical and visually disabled people who have the right to vote and living in Malatya. The data obtained from the interviews were analyzed on three axes from the "facilities", "materials" and "voting procedures" which are noted in the United Nations Convention on the Rights of Persons with Disabilities.

Keywords: Disabled people, Disability rights, Political participation, Elections, Voting.

\section{Giriş}

Engellilik, literatürde temelde iki ana söylem ya da kuramsal model çerçevesinde sınıflandırma yapılarak açıklanmıştır. İlk model olan "tıbbi model” (geleneksel bireyci tıbbi) engelliliği, bireyin kendisinden kaynaklanan, bireye ait bir "eksiklik" veya "hastalık" hatta bir "şanssızlık" olarak görmekte ve dolayısıyla ortadan kaldırılması gereken kişisel bir durum, tıbbi bir dil ile tedavi edilmesi gereken bir sorun olarak görmektedir. Engelliliğin bireysel bir sorun olarak algılanması ile birlikte, bilgi-iktidar arasındaki ilişkinin bir sonucu olarak sağlık çalışanları da bu sorunu iyileştirmekle yükümlü olan bir iktidar grubu olarak kabul edilmiştir (Bezmez, Yardımcı \& Şentürk, 2011, s.18). Dolayısıyla tıbbi modele göre engellilik bireyin başına doğuştan ya da sonradan gelmiş olan bir talihsizlik, bir eksiklik veya bir hastalık durumu olarak tanımlanmıştır (Burcu, 2015, s. 23).

1970'li ylllarda Driedger (1989)'in ifadesiyle "son medeni (civil) haklar hareketi" olan engelli hakları hareketi ile birlikte engelliliğin sosyal modeli gelişmiștir. Engelliliğin sosyal modeli, bu döneme kadar egemen söylem olan tıbbi modele karşı bir tepki olarak gelişmiştir. Sosyal modelin birçok türü bulunmakla birlikte sosyal model, engelliliği bireyden çok toplumun bir sorunu olarak görmekte, toplumda gerekli koşulların ve düzenlemelerin sağlanması durumunda, engelli bireylerin yaşamın her alanına katılabilecekleri gerçeğini vurgulamaktadır. Dolayısıyla her ne kadar sorun beden veya zihinle birleşmiş nesnel bir gerçeklik olarak ele alınsa da sorunun kaynağı engelli olan kişi değil, egemen toplumsal pratikler ve toplumsal çevredir (Bezmez vd.,2011, s.19; Burcu, 2015, s.25-26). Dolayısıyla sosyal model ile engellilik meselesi bireysel olandan toplumsal olana taşınır ve böylece bireyin değil toplumun değişmesini öngörür (Shakespeare, 2011, s.55). Engellileri yardıma muhtaç veya tedavi edilmesi gereken "sakat" olarak gören modeller ve söylemler yerini, engellilerin de diğer vatandaşlar gibi aynı temel insan haklarına sahip olduğu varsayımından hareket eden modeller ve söylemlere bırakmaya başlamıștır. Nitekim sosyal model engellilik tartışmalarını ve söylemi "tıbbi model"in belirlediği egemen gündem yerine, gündemi siyaset ve vatandaşlık söylemlerine kaydırmakta başarılı olmuştur (Hughes, 2011, s.63). Bunu küresel ve bölgesel ölçekte Birleşmiş Milletler, Avrupa Birliği gibi ulus-üstü kuruluşların çeşitli karar ve politika belgelerinde açıkça görebilmek mümkündür. Nitekim Birleșmiș Milletler Engellilerin Haklarına İlişkin Sözleşme'nin giriş kısmında şu șekilde ifade 
edilmiştir: "Engelliliğin gelişen bir kavram olduğunu ve engellilik durumunun, sakatlı̆̆ olan kişilerin topluma diğer bireyler ile birlikte eşit koşullarda tam ve etkin katılımını engelleyen tutumlar ve çevre koşullarının etkileșiminden kaynaklandığı gerçeğini kabul ederek" (Birleşmiş Milletler (BM) Engellilerin Haklarına İlişkin Sözleşme, 2006, (e) bendi).

Küresel düzeyde engelli hakları bakımından en temel belgelerden biri olan Birleşmiş Milletler (BM) Engellilerin Haklarına İlişkin Sözleşme'de "engelli" kavramı "diğer bireylerle eşit koşullar altında topluma tam ve etkin bir şekilde katılımlarının önünde engel teșkil eden uzun süreli fiziksel, zihinsel, düşünsel ya da algisal bozukluğu bulunan kişileri" ifade edecek biçimde tanımlanmıștır (BM Engellilerin Haklarına İlișkin Sözleşme, 2006, (m.1). Bununla birlikte Gül \& Karan (2011: s.55)'ın tespit ettiklerine göre BM Sözleşmesi'nin resmi Türkçe çevirisi, engelliliği doğuran unsurları engelli bireyin niteliklerinden kaynaklandığı anlamına gelecek biçimde eksik yapılmıştır. Orijinal İngilizce metninde tanım șu șekilde yapılmıștır: "Engelli kişiler, diğerleri yanında, çeşitli engellerle etkileşerek kişinin diğerleriyle eşit bir şekilde topluma tam ve etkili şekilde katılmasını engelleyen uzun süreli fiziksel, zihinsel, ruhsal ve duyusal sakatlığı olan kişileri de kapsar". Dolayısıyla BM Sözleşmesi'nin ruhuna da uygun olarak orijinal metinde yer alan tanıma göre, "engellilik kişinin kendi nitelikleriyle, bu nitelikleri göz ardı ederek oluşturulmuş dış engellerin birleşmesinden doğmaktadır" (Gül \& Karan, 2011: s.55). Özellikle BM Sözleşmesi'nde bu șekliyle benimsenen sosyal model anlayışı, yardıma muhtaç, tedavi edilmesi gerekli hasta gibi egemen söylemlerin biçimlendirdiği engellilere dönük olan toplumsal algı ve tutumların değişmesi yanında BM Sözleşmesini imzalayan hükümetlere, engelli bireylere diğer vatandaşlarla aynı hakları garanti etme ve bu hakları korumak bakımından sorumluluk yüklemesi açısından da oldukça önemlidir. Dolayısıyla engelliliğe ilișkin söylemler ve engellilik konusu günümüzde daha çok bir insan hakları meselesi olarak ele alınmaktadır.

Birçok insan için, seçimlerde oy kullanmak, en temel ve doğrudan gerçekleștirilebilen bir siyasal faaliyet türüdür. Engelli bireylerin seçimlerde oy kullanmalarının sağlanması, engelli olmayanlarla eşitliğin sağlanması ve BM Sözleşmesinde belirtilen "engelliliğe dayalı ayrımcılık"ın ortadan kaldırılması açısından da son derece önem taşıyan bir konudur.

Bu çalışmanın yanıt aradığı sorular şunlardır:

1) Engelli bireyler oy verme sürecinde ne gibi zorluklar yaşamaktadırlar?

2) Türkiye'de engelli bireyler için seçimlerde oy kullanmayı teşvik eden araçlar, mekanizmalar nelerdir? Bunlar yeterli midir?

Araştırma sorularına uygun olarak bu çalışma, Birleşmiş Milletler Engellilerin Haklarına İlişkin Sözleşmede dikkat çekilen "tesisler", "seçim materyalleri" ve "seçim usulleri" olmak üzere üç eksen üzerine oturtulmuştur. Çalışma kapsamında Malatya'da yaşayan bedensel ve görme engelli on beş seçmen ile 24 Haziran 2018 seçimlerinden önce Nisan-Mayıs 2018'de ve 24 Haziran seçimlerinden hemen sonra Temmuz 2018'de derinlemesine yüzyüze görüşme gerçekleștirilmiştir. Yine ayrıca bu tarihler arasında “Görmeyenler Kültür ve Birleşme Derneği Malatya Şubesi”nde dernek üyesi çeşitli katılımcılarla odak grup görüşmesi de yapılmıştır. 


\section{Siyasal Katılım, Seçimler ve Engellilik}

Siyasal katılım kavramı vatandaşların yönetimlerin yapısını, oluşumunu ya da kamu politikalarını etkilemek amacıyla başvurdukları çeşitli yolları anlatmak için kullanılır (Hague \& Harrop, 2017, s.155). Siyasal katılım, televizyondan toplum ve dünya sorunlarıyla ilgili haberleri takip etmek, seçimlerde oy kullanmak, vatandaşların siyasetçiler veya bürokratlarla mektup, elektronik posta veya sosyal medya yolu ile iletişim halinde olarak onların kararlarını etkilemek, kendileri ya da başkaları tarafından tasarlanmış hukuki veya hukuk dışı gösteri yürüyüşüne katılmak, eylemler gerçekleştirmek, yasadışı örgütlere ilgi duymak, siyasal parti toplantılarına katılmak, siyasal partilere üye olarak çeşitli görevler almak gibi oldukça geniş ve farklı boyutlarda gerçekleştirilebilir (Özbudun, 1975'ten aktaran, Altan, 2011: s.313-329). Siyasal katılım böylesine farklı boyutlarda gerçekleşmekle birlikte bireyler, siyasal katılımı ilgi düzeylerine göre farklı biçimlerde deneyimlerler. Bu bağlamda Milbraith, gözlemci eylemler, aracı eylemler ve siyasal mücadeleye yönelik eylemler biçiminde yapmış olduğu sınıflandırma ile siyasal katılımın yoğunluk düzeyine göre bir sıralama yapmıştır. Dolayısıyla siyasal katılım, siyasete ilgisizlik, yani katılmamadan, yalnızca seçimden seçime oy kullanmayla sınırlı bir faaliyet ya da siyasal partilere üye olma ve siyasal eylemlere katılma biçiminde gerçekleşebilir (Kışlalı, 2003, s.222; Çam, 2002, s.172-173).

Yalnızca bireylerin kişisel özellikleri değil, toplumların yapısı, siyasal kültür ile siyasal sistemin niteliği siyasal katılımın biçimini ve niteliğini belirleyici özelliğe sahiptir (Akyol, 2016, s.317). Yapılan birçok çalışmanın ortaya koyduğu gibi; boş vakti olan, erkek, eğitimli, kentlileșmiș, orta yaşl, evli, yüksek statü ve yüksek gelir sahibi, serbest meslek gruplarından bir mesleğe sahip olmak gibi niteliklere sahip olan bireylerin siyasal hayata daha fazla katılacağı beklenmektedir (Roskin, Cord, Medeiros \& Jones, 2015, s.250-254; Lipset, 1986, s.169; Kışlalı, 2003, s.223; Prince, 2014, s.94-120). Genel olarak söylemek gerekirse bir siyasal katılım türü olan oy vermeyi belirleyen etkenler aynı zamanda daha önce ifade edilen genel olarak siyasal katılmayı belirleyen etkenler ile neredeyse aynıdır. Bu çalışmada, siyasete katılımın bilinen en yaygın ve niceliksel boyutu en kolay tespit edilebilecek türü olan seçimlerde oy verme süreci, engelli bireylerin yaşadıkları sorunlar açısından ele alınmıştır (Hall \& Alvarez, 2012, s.8). Toplumsal cinsiyet, ırk, etnisite, eğitim, gelir gibi eşitsizlikler siyasal katılım üzerinde belirleyicidir. Siyasal katılım üzerinde belirleyici olan en önemli iki demografik özellik ise eğitim ve gelir düzeyidir (Roskin vd. 2015, s. 251). Bu iki özellik açısından engelli bireyler ile engelli olmayanlar arasında önemli farklar bulunmaktadır. Birçok ülkede engelli bireylerin engelli olmayan bireylere göre sosyo-ekonomik yönden daha kötü durumda olmasının yanı sıra damgalama ve toplumsal dışlanmaya maruz kalmaları, engelli bireylerin mevcut sınırlamaları aşmalarını giderek daha da zorlaştırmaktadır (Mattila \& Papageorgiou, 2017, s.505-519; Sackey, 2015, s.366-381). ABD’de engelli bireylerin $\% 9$ gibi bir oranla engelli olmayanlara göre daha fazla yoksulluk sinırında oldukları tespit edilmiştir (Hall \& Alvarez, 2012, s.2). Sosyal politikalar yönünden son derece güçlü olan Avrupa Birliği'nde (AB) dahi engelliler arasında yoksulluk oranı 
ortalamanın \%70 üzerindedir (Avrupa Engellilik Stratejisi 2010-2020, 2010: s.3). Tüm bu verilerin ışı̆̆ında engelli bireyler, engellerinden dolayı (fiziksel, zihinsel, görme vs.) genel olarak diğer bireylere oranla daha düşük düzeyde siyasal katılım gerçekleștirirler. Dolayısıyla engelli bireyler açısından bakıldığında engellilik siyasal katılım üzerinde belirleyicidir. Ayrıca engelliliğin fiziksel veya zihinsel kaynaklı sınırlamalarını karşılamak ve aşmak adına engelli bireyler daha fazla zaman, çaba ve para harcamaya da ihtiyaç duyarlar (Schur, Shields, Kruse \& Schriner, 2002).

Engelli bireylerin toplumun birbirinden son derece farklı etnik, dini, sosyoekonomik ve toplumsal cinsiyet gruplarına mensubiyetleri olabilmektedir. Güncel insan hakları hukukunun yanında toplumun böylesine büyük ve aynı zamanda da böylesine birbirinden farklı toplumsal bölünmüşlük eksenleri ile de kesişen bir kesimi siyasete katılmadığı takdirde demokrasinin derinleşmesini ve tüm bireylerin siyasete ve yönetime katılmasını beklemek olanaksız görünmektedir (International Foundation for Electoral Systems (IFES), 2014, s.3-4; Engelsiz Türkiye İçin: Yolun Neresindeyiz, 2013).

Yapılan birçok çalışma göstermiştir ki genel olarak engelli bireylerin siyasal eylemlere katılım düzeyleri engelli olmayanlara göre daha düşük düzeydedir (Schur, 2003, s.31; Schur \& Adya, 2013, s.811-839; Schur, Shields \& Schriner, 2005). Ancak, bazı ilginç istisnai durumlar da tespit edilmiştir. Örneğin engelli bireylerin engelli olmayan bireylere göre bir siyasal katılma biçimi olan siyasetçiler veya bürokratlarla iletişim kurma olasılığı daha yüksektir (Schur \& Adya, 2013, s.818). Ayrıca, bazı ilginç cinsiyet farklılıkları vardır. Engelli kadınların genel olarak siyasete katılma olasılıkları daha düşük düzeyde olmasına rağmen, engelli kadınların daha fazla protesto ya da yürüyüșe katılma eğiliminde oldukları tespit edilmiştir (Schur, 2003, s.31). Yine ayrıca engelli bireyler arasında, engellilere karşı ayrımcılık olduğunu algılayanların algılamayanlara göre siyasal açıdan daha aktif oldukları da saptanmıştır (Mattila \& Papageorgiou, 2017, s.505-519).

ABD'de engelli bireylerin seçime katılım oranı genel nüfusa oranla \%3-20 arasında değișen bir oranla daha düşük düzeydedir (Schur \& Adya, 2013, s.818; Schur vd. 2002). Grammenos (2013, s.509) ise Avrupa Sosyal Araştırma verilerini kullanarak Avrupa'da engelli bireyler arasında oy verme faaliyeti üzerine yapmış olduğu çalışmada engelli ve engelli olmayan bireyler arasında seçime katılım oranı bakımından sekiz puanlık bir fark bulmuştur. Her ne kadar engelli bireylerin genel olarak seçimlere katılım oranı engelli olmayan bireylere göre daha düşük olsa da engelli bireylerin çalışma durumu, istihdam edilmesi gibi olumlu gelişmelerin engelli bireylerin siyasal hayata katılmasını kolaylaştırdığı yapılan çalıșmalarla da ortaya konulmuştur. Nitekim Schur vd. (2005)'nin yaptıkları çalışmada engelliler grubundaki en düşük katılım oranlarının işsizler ve yaşlılar arasında olduğu tespit edilmiştir. Ayrıca ABD’de genç engelli bireylerin seçimlere katılım oranı ile aynı yaş grubundaki engelli olmayan bireylerin seçime katılım oranları arasında önemli benzerlikler bulunduğu da dikkat çekmiştir (Schur, Shields \& Schriner, 2005). 


\section{Engelliler ve Siyasal Katılım Üzerine Literatür}

Birçok çalışmada genel olarak oy vermede rol oynayan çeşitli etkenler tespit edilmiștir (Lipset, 1986; Turan, 1977). Ancak özel olarak engelli bireylerin oy vermeleri üzerinde rol oynayan etkenleri inceleyen araştırmaların sayısı sınırlıdır. Engelli bireylerin siyasal katılımı ve özel olarak oy verme üzerine çalışmalar daha çok ABD'de yapılmaktadır. Schur ve Douglas (2000) yaptıkları çalışmada engelli bireyler arasında oy verme oranını araştırmışlarken, yapılan birçok çalışmada engelli bireylerin oy vermekten kaçınmalarında ya da oy vermemelerinde rol oynayan en önemli etkenlerden birinin oy kullanma alanlarının, binaların fiziksel olarak engelli seçmenlere uygun olmaması konusu ileri sürülmüştür. Bu konuda Schur vd. (2017) yaptıkları çalışmada oy verme yerine ulașlabilirlik ile engellilerin oy kullanma oranları, engellilerin oy kullanırken yaşadıkları zorlukları araștırmışlardır. Bu çalışmanın verilerine göre ABD 2012 seçimlerinde yaklaşık \%30 oranındaki engelli seçmen oy kullanılan binanın zorluklarını dile getirmişken, bu oran engelli olmayan bireylerde \%8.4 kadardır. Bunun dışında engelli bireylerin büyük bölümünün içinde bulunduğu sürekli işsizlik gibi sosyoekonomik faktörler ile karşı karşıya kaldıkları damgalama ve sosyal dışlanma süreçleri engelli bireylerin seçimlere katılımını teşvik etmek bir yana; aksine onların oy vermekten kaçınmalarında önemli rol oynamaktadır (Schur vd. 2002; Priestley vd. 2016, s.1-9). Mattila ve Papageorgiou (2017), yapmış oldukları çalışmada oy kullanma, siyasetçiler veya hükümet yetkilileri ile iletişim kurmak ve yasal gösterilere katılmak gibi üç tür siyasal katılım üzerine yoğunlaşmışlardır.

Engelli bireylerin siyasal yaşama olan ilgi düzeylerini tespit etmek için Birleşmiş Milletler Engelli Hakları Sözleşmesi'ne dayanarak, kurumsal düzeyde Avrupa Birliği Temel Haklar Ajansı (European Union Agency for Fundamental Rights-FRA) ve ANED (The Academic Network of European Disability Experts), iki ana uluslararası sosyal anket olan Avrupa Yaşam Kalitesi Anketi (EQLS) ve Avrupa Sosyal Araştırması (ESS) verilerini analiz etmişlerdir. Bu çalışmalardan çıkan verilere göre $A B$ üyesi devletlerin, engelli bireylerin siyasi katılım haklarının ulusal mevzuat ve politika çerçevelerine dâhil edilmesinde önemli ilerlemeler kaydettikleri tespit edilmiştir. FRA'nın ve ANED'in analizinden çıkan ilk mesaj son derece olumlu ve önemlidir: "erişilebilir ve olanaklı bir ortam sağlandığı takdirde engelli bireyler kendi toplumlarının siyasal yaşamına katılmaya hevesli birer aktif vatandaştır". Örneğin, ESS anketine katılanlara siyasete ne kadar ilgi duydukları sorulmuştur. Anket kapsamındaki AB üyesi devletlerin çoğunda, engelli katılımcıların siyasete olan ilgisinin genel nüfusa göre daha fazla olduğu yani daha ilgili oldukları görülmüştür. Hatta Çekya, İrlanda ve Slovakya'da engelli katılımcıların genel nüfusa göre ilgilerinin çok daha fazla olduğu da tespit edilmiştir (FRA, 2014, s.21). Ayrıca AB'ye üye devletlerin çoğunda, engelli bireylerin son ulusal seçimlerde genel nüfustan daha fazla oy kullandıkları da görülmüștür. Ancak bu durumun önemli ölçüde Avrupa nüfusunun giderek yaşlanması sonucunda engelli olduğunu bildiren yaşlı insanların sayısının artması ve böylece oy kullanması sonucunda ortaya çıkmış olduğu düşünülmektedir (FRA, 2014, s.23).

Uluslararası Seçim Sistemleri Vakfı'ndan (IFES) V.Atkinson ve Ulusal Demokratik Enstitüsü'nden (NDI) A.Azelton ve K.Fogg tarafından "Eşit Erişim: Seçimlerde ve Siyasi 
Süreçlerde Engelli Kişilerin Dâhil Edilmesi” başlıklı bir el kitabı hazırlanmıștır. El kitabı engelli bireylerin seçimlere ve siyasi süreçlere katılımının güçlendirilmesi için çeşitli stratejiler ve araçlar sunan bir içerikte hazırlanmıştır (International Foundation for Electoral Systems (IFES), 2014, s.3-4).

\section{Türkiye'de Seçimlere İlişkin Esaslar ve Engelli Bireylerin Seçimlere Katılımına Yönelik Düzenlemeler}

Türkiye'de seçimlerin genel çerçevesi, 1961 tarihli ve 298 sayılı "Seçimlerin Temel Hükümleri ve Seçmen Kütükleri Hakkında Kanun”, 1983 tarihli 2820 sayılı "Siyasi Partiler Kanunu", 1983 tarihli 2839 sayılı "Milletvekili Seçim Kanunu”, 1982 Anayasası ve 2017 tarihli 7062 sayılı "Yüksek Seçim Kurulunun Teşkilat ve Görevleri Hakkında Kanun" tarafından oluşturulmuştur.

Engelli bireylerin seçim sürecine katılımı yani oy kullanmaya ilişkin düzenlemeler de bunların içerisinde yer almıştır. 1982 Anayasası'nın "Seçme, seçilme ve siyasi faaliyette bulunma hakları"nı düzenleyen 67. maddesinin 3. fikrasında, "Onsekiz yaşını dolduran her Türk vatandaşı"nın seçme, seçilme ve siyasi faaliyette bulunma hakkına sahip olduğu" belirtildikten sonra; 4. fikrada, sözkonusu hakların "kanunla düzenleneceği" kuralı getirilmiştir. Seçmen olmaya ilişkin düzenleme ise 1961 tarihli ve 298 sayılı "Seçimlerin Temel Hükümleri ve Seçmen Kütükleri Hakkında Kanun" tarafından düzenlenmiştir. Seçimlere engelliler açısından bakıldığında, kanunun 8. maddesinde "Kısıtlı olanlar"ın seçmen olamayacağı biçiminde düzenlenmiştir ${ }^{1}$. Bu çalışmanın kapsamı açısından bakıldığında kısıtlı olup seçmen olamayacaklar, vesayet altında olan psikiyatrik sorunları olanlar ile zihinsel engellilerdir. Ayrıca zihinsel engelliler adına vasisi de oy kullanamamaktadır. Görüldüğü gibi Türkiye'de siyasal katılım, tüm engelliler için de aynı anlama gelmemekte, zihinsel engelli bireylerin siyasal yaşama katılım hakları bulunmamaktadır. Bu konuda birçok ülkede farklı uygulamalar söz konusudur. 28 üyeli AB'de, üyelerden yedisi: Avusturya, Hırvatistan, İtalya, Letonya, Hollanda, İsveç ve Birleşik Krallık, kısıtlı olanlar da dâhil olmak üzere engelli herkes için oy kullanma hakkını tanımıștır. Macaristan'da, 2012 yılına kadar vesayet altında olan herkes, oy kullanma hakkından yoksunken, bu tarihten sonra bu düzenleme değiştirilmiş ve hâkimlerin "sınırlı zihinsel kapasiteye sahip" bireylerin oy kullanmasına izin verilip verilmeyeceğine ilişkin karar vermelerine ilişkin düzenleme yapılmıștır (FRA, 2014, s.23; Schriner, Ochs \& Shields, 1997, s.75-96).

Siyasete ve yönetime katılımın herkesin hakkı olduğu, bunun da özellikle genel ve eşit oya dayanan gizli oy ve serbest seçimler yoluyla gerçekleştirilmesine ilişkin düzenlemeler, en başta 1948 tarihli İnsan Hakları Evrensel Beyannamesinde yer almıştır. Ayrıca 1966 yılında BM Genel Kurul kararıyla kabul edilen ve 1976 yılında yürürlüğe giren ve Türkiye'nin 2000 yılında Avrupa Birliği muktesebatına uyum sürecinde imzaladığı "Medeni ve Siyasi Haklara İlişkin Uluslararası Sözleşme"de de düzenlenmiştir. Uluslararası alanda engelli bireylerin siyasal katılım hakkı, en üst

1 Türk Medeni Kanunu'ndaki "kısıtlı olma hali”nin nedenleri ise “a) Akıl hastalığı veya akıl zayıflı̆̆ı,

b) Savurganlık, alkol veya uyuşturucu madde bağımlılığı, kötü yaşama tarzı, kötü yönetim, c)

Özgürlüğü bağlayıcı ceza ile d) istek üzerine" sayılmıştır. 
düzeyde Birleşmiş Milletler (BM) Engellilerin Haklarına İlişkin Sözleşme (CRPD), Avrupa Konseyi ve Avrupa Birliği gibi kuruluşların oluşturduğu uluslararası hukuk çerçevesinde düzenlenmiştir. Avrupa Birliği Temel Haklar Ajansı (FRA) ve Avrupa Komisyonu tarafından finanse edilen Avrupa Engellilik Uzmanları Akademisi (ANED) ise Avrupa Birliği üyesi ülkelerin verilerini toplayarak, engelli bireylerin siyasal katılım hakkının düzeyini gösteren araştırmalar gerçekleştirmektedir.

BM tarafından 2006 yılında kabul edilen, Birleşmiş Milletler (BM) "Engellilerin Haklarına İlişkin Sözleşme” Mart 2007'de ise imzaya açılmıştır. Türkiye, Sözleşme’yi imzaya açıldığı ilk gün imzalayan devletler arasında yer almıștır. 2009 yılında Türkiye tarafından onaylanması uygun bulunan sözleşme resmî gazetede yayınlanarak yürürlüğe girmiştir. Sözleşmenin Ek İhtiyari Protokolü de aynı yıl imzalanmış, onay süreci Mart 2015’te tamamlanmıștır. Sözleșmenin 29. Maddesi “Siyasal ve Toplumsal Yaşama Katılım” başlığını taşımaktadır. Maddeye göre sözleşmeye taraf devletlerin engellilerin siyasi haklarını ve diğer bireylerle eşit koşullar altında bunlardan yararlanma fırsatını güvence altına alacağını belirterek, ayrıca taraf devletlerin yerine getirecekleri konuları sıralamıștır. Buna göre:

(a) Diğerlerinin yanısıra aşağıda belirtilenler yoluyla, engellilerin diğer bireylerle eşit koşullar altında seçme ve seçilme hakları dâhil olmak üzere siyasi ve kamusal yaşama etkin şekilde ve tam katılımını doğrudan veya serbestçe seçilmiş temsilciler aracılığıyla sağlamak,

(i) Seçim usullerinin, tesislerinin, materyallerinin uygun, erişilebilir ve anlaşılması ve kullanılmasının kolay olmasını sağlamak,

(ii) Engellilerin, seçimlerde ve referandumlarda baskıya uğramadan, gizli oy kullanarak, aday olma ve etkili bir mevkide görev alma ve devletin tüm kademelerinde tüm kamu görevlerini yerine getirme haklarını koruyarak, uygun olan yardımcı ve yeni teknolojilerin kullanılmasını kolaylaştırmak,

(iii) Engellilerin seçmen olarak tercihlerini özgürce ifade edebilmelerini güvence altına alarak ve bu amaçla gerektiğinde, talep etmeleri durumunda oy kullanırken kendi seçtikleri bir kişinin desteğini almalarına izin vermek,

(b) Engellilerin ayrımcılığa uğramadan, diğer bireylerle eșit koşullar altında, kamu işlerinin idaresinde etkin ve tam katılımlarının sağlanacağı bir ortamı yaratmak ve aşağıda belirtilenler de dâhil olmak üzere, kamu işlerine katılımlarının cesaretlendirmek;

(i) Ülkenin kamusal ve siyasi yaşamı ile ilgili sivil toplum kuruluşları, dernekler ve siyasi partilerin etkinliklerine ve yönetimine katılım;

(ii) Engellileri uluslararası, ulusal, bölgesel ve yerel düzeylerde temsil eden engelli örgütlerinin kurulması ve engellilerin içinde yer almalarının sağlanması.

Son yıllarda en başta Birleşmiş Milletler "Engellilerin Haklarına İlişkin Sözleşme” olmak üzere birçok düzenleme ile engelli haklarında önemli bir gelişmenin yaşandığı ve bununla birlikte engelli bireylerin daha fazla siyasal haklara sahip olması yönünde talepler giderek daha fazla görünürlük kazanmıştır. Sözleşmenin etkisi ile Batı'da engelli seçmenlerin seçimlere katılımını artırmaya dönük birçok gelişme yaşanmıştır. 
Birleşmiş Milletler Engellilerin Haklarına İlişkin Sözleşmede düzenlenen ve uygulamada yaşanan gelişmeleri üç gruba ayırarak incelemek mümkündür. İlk olarak Sözleşmenin 29. Maddesinin (a) bendinin ilk fikrasındaki düzenlemeye uygun olarak "tesisler" açısından fiziksel engelli bireylerin seçimlere katılımını artırmaya dönük olarak oy kullanılan binaların mimari açıdan yeniden tasarlanması ve böylece seçim sandığına fiziksel engelli bireylerin erişiminin sağlanması. İkinci olarak seçim "materyallerinin" görme engelli bireyler başta olmak üzere engelli bireylerin seçimlerde kendi başlarına oy kullanma olanaklarının artırılmasına dönük olarak özel oy pusulalarının geliştirilmesi ve üçüncü olarak "seçim usulleri" çerçevesinde tüm engel grupları dâhil olmak üzere, ağır yatağa bağımlı hasta, yaşlı bireyleri de kapsayacak şekilde bulunulan yerden farklı yöntemlerle oy kullanma olanağının sağlanması anlamında alternatif oy verme tekniklerinin, sözleşmenin öngördüğü biçimde "uygun", "erişilebilir" ve "anlaşılması ve kullanılmasının kolay olması" ölçütleri açısından değerlendirilmiştir. Birleşmiş Milletler esas alınarak Avrupa Birliği Temel Haklar Ajansı (European Union Agency for Fundamental Rights-FRA) engelli kişilerin siyasal katılım hakları ile ilgili çeşitli göstergeler hazırlamaktadır. Buna göre veriler, dört anahtar temaya göre gruplandırılmıștır: "Yasal ve idari engellerin kaldırılması, engelli kişilerin siyasal katılım haklarına ilişkin farkındalığın artırılması, oy kullanma süreçlerinin ve seçim materyallerinin daha erişilebilir olması ve siyasal katılım için olanakların genişletilmesi”. Ayrıca Avrupa Birliği'nde 2004-2010 "Engelli Eylem Planının” deneyimi ile Kasım 2010'da "Avrupa Engellilik Stratejisi 2010-2020" kabul edilmiștir. Strateji BM Engelli Hakları Sözleşmesi'ne (UNCRPD) dayanan ve onu tamamlayıcı nitelikte olan bir belge olarak engelli bireylerin toplum ve ekonomiye tam ve eşit katılım hakkını ortaya koymaktadır. Avrupa Engellilik Stratejisi sekiz öncelikli alana odaklanmaktadır: erişilebilirlik, katılım, eșitlik, istihdam, eğitim ve öğretim, sosyal koruma, sağlık ve dış eylem.

\section{A. Seçimler, Tesisler ve Erişilebilirlik}

Oy kullanma yerine ulaşılabilirlik, engelli bireylerin siyasal katılımını etkileyen en temel etkendir (Schur \& Adya, 2017, s.1375). Nitekim bedensel engelli (A11) yaşadıkları en büyük sorunun oy kullanılan binaların mimari açıdan uygun olmaması ve ulaşımla ilgili olduğunu ifade etmiştir. Son yıllarda Batı'da engellilerin seçimlere katılım oranını artıran en önemli gelişmelerden biri, seçim sandıklarının bulunduğu binaların mimari açıdan yeniden tasarlanması olmuştur. BM Engellilerin Haklarına İlişkin Sözleşmenin 9.maddesi "Erişilebilirlik" başlığı altında taraf devletlere kamu binaları, yollar vs. ile bilgi ve iletişim araçlarına engellilerin erişiminin önündeki engellerin ortadan kaldırılması konusunda tedbirlerin alınmasını yükler. Ülkemizde 2005 yılında çıkarılan 5378 sayılı "Engelliler Hakkında Kanun”un yayımlanması ile birlikte önemli bir dönüşüm başlamıştır. Kanun BM sözleşmesi ile paralel olarak erişilebilirlik başlığı altında binaların, ulaşım, bilgi ve iletişim teknolojisinin engelliler tarafından bağımsız olarak ulaşılabilir ve kullanılabilir hale getirilmesini hedeflemektedir (5378 Sayılı Engelliler Hakkında Kanun (EHK), m.3-7). Ayrıca kanun, kamu kurum ve kuruluşlarına ait resmi yapılar vs.nin kanunun yürürlüğe girdiği tarihten itibaren sekiz yıl içerisinde 
engellilerin erişilebilirliğine uygun duruma getirileceğini belirtmektedir (5378 Sayılı Engelliler Hakkında Kanun (EHK), geçici m.2).

Türkiye'de seçimlerin genel çerçevesini belirleyen 1961 tarihli ve 298 sayılı Seçimlerin Temel Hükümleri ve Seçmen Kütükleri Hakkında Kanunun çeşitli maddelerinde engelli, yaşlı ve hasta seçmenlerin seçim sandığına erişmesini sağlayacak çeşitli düzenlemeler bulunmaktadır: Buna göre, "sandıkların konulacağı yerleri ve oy verme işinin vaktinde sona ermesi için gerekli tedbirleri ilçe seçim kurullarının denetiminde sandık kurulu tespit eder. Sandıkların konulacağı yerlerin belirlenmesinde seçmenin oyunu kolaylıkla, serbestçe ve gizli şekilde verebilmesi gözetilir. Engelli seçmenlerin oylarını rahatlıkla kullanabilmeleri için gerekli tedbirler alınır....(m.74) “...0y verme günü sandık başına gelecek seçmenler, sandık kurulu önüne başkan tarafından sıra ile birer birer alınırlar. Gebeler, hastalar ve engelliler bekletilmezler. Yaşlılar önce alınabilirler (m.90)". Ayrıca “Sandık Kurullarının Oluşumu ile Görev ve Yetkileri” başlıklı 135 Sayll genelgede "Görme engelliler, felçliler, elleri eksik olanlar veya bu gibi bedeni engelleri açıkça belli olanlar o seçim çevresi seçmeni olan ve o sırada sandık çevresinde bulunan akrabalarından birinin, akrabası yoksa diğer herhangi bir seçmenin yardımı ile oylarını kullanabilirler. Bir seçmen birden fazla engelliye yardım edemez. Sandık kurulu başkan ve üyeleri engelli seçmenlere yardım etmek amacıyla oy verme kabinine giremez, oy kullanma sırasında yardım edemez." Biçiminde düzenleme yapılmıștır.

Her ne kadar kanunda engelli seçmenlerin oylarını rahatlıkla kullanabilmeleri ve seçim sandığına erişilebilirliği sağlamak bakımından gerekli tedbirlerin alınacağı ifade edilse de uygulamada, Yüksek Seçim Kurulu'nun kayıtlarındaki engelli seçmen sayısı ile seçimlere katılan engelli birey sayısı birbirinden farklı olmaktadır. Yani birçok engelli bireyin engel durumu YSK kayıtlarına bildirilmediği için YSK kayıtlarındaki engelli seçmen sayısı gerçekteki engelli seçmen sayısından daha az görünmektedir. Bu durumda ise kimi zaman engelli bireylerin oy kullanacakları sandıkların binanın giriş katına değil, binanın üst katlarına konulduğu görülmektedir. Seçim sandıklarının konulduğu binaların bedensel engelli bireyler için uygun olmaması durumunda da engelli bireyler oy kullanmaktan kaçınmakta ya da yakınları tarafından bina içerisinde üst katlara taşınmaktadır. Nitekim bu durumu tespit eden bir çalışmanın bulgularına göre², YSK verilerinde, nüfusunun \%12.29'u engelli olan Türkiye'de engellilerin seçmenler içindeki oranı yalnızca \%0.33'tür ve toplam 165.293 engelli seçmen bulunmaktadır. Raporu hazırlayanlara göre bu veri YSK'nın engelli seçmenlerin bilgilerine ve engelli bireylerin seçimlere etkin katılımı için herhangi bir politikaya sahip olmadığını göstermektedir (Türkiye'de Engellilere Yönelik Ayrımcılık Hak İhlalleri 2011 Yılı İzleme Raporu, 2011, s.46). YSK kayıtlarındaki engelli seçmen sayısı ile gerçekte var olan ancak seçmen bilgi sisteminde engelli olarak görünmeyen seçmenler arasındaki böylesi fark, BM Engellilerin Haklarına İlişkin Sözleşmenin öngördüğü seçimden önce gerekli oy pusulası önlemlerini almak, oy sandığını binanın birinci katına yerleștirmek gibi düzenlemeleri yapmayı olanaksız hale getirmektedir. Nitekim bedensel engelli (A1) hayatında iki defa

\footnotetext{
212 Haziran 2011 tarihinde 24. Dönem Milletvekili Genel Seçimleri, İzleme Platformu tarafından 10 ilde dezavantajlı grupların seçme ve seçilme haklarına erişimi izlenmiş ve raporlanmıştır. Eşit Haklar İçin İzleme Derneği (ESHID), “Türkiye’de Engellilere Yönelik Ayrımcılık Hak İhlalleri 2011 Yılı İzleme Raporu”, (Yay. haz. Mahir Işık vd.), Ankara, EŞHID Yayınları.
} 
oy kullandığını, bunun birinin köyde babası tarafından, diğerinin ise şehirde kendisi tarafından kullanıldığını belirtmiştir. Aynı engelli seçmen seçimlerde oy kullanmanın kendisine çekici gelmemesini, binaların tekerlekli sandalyesi için uygun olmamasına yani erişilebilirlik sorununa bağlamaktadır. Gelecek seçimlerde oy kullanıp kullanmayacağı ile ilgili soruya "Kimseye yük olmak istemiyorum" biçiminde yanıtlayarak oy kullanmayacağını ifade etmiştir.

Türkiye'de seçimlerin yönetimini üstlenen YSK'nın görev ve yetkileri ile çalışma usul ve esasları 2017 tarih 7062 sayılı "Yüksek Seçim Kurulunun Teşkilat ve Görevleri Hakkında Kanun" ile düzenlenmiştir. 7062 sayılı kanunun 6. Maddesi, "Kurulun Görev ve Yetkileri" başlığı altında "g" bendinden kurula, açıkça "Engelli seçmenlerin oy kullanmalarını kolaylaştıracak her türlü tedbiri almak" görevini vermiștir. Kurula böyle bir görevin verilmesi önemli bir gelişmedir. Dolayısıyla bu yıla kadar çeșitli kanunlarda ve yönetmeliklerle düzenlenen YSK'nın görev ve yetkilerinin ayrı bir kanunla düzenlenmiş olması ve kanuna da engellilerin oy kullanmalarının kolaylaştırılması görevi eklenmiş olması bundan sonraki dönemlerde yapılacak olan seçimlerde engelli seçmenlerin oy kullanma olanaklarının artırılması ve böylece engelliliğe dayanan toplumsal eşitsizliklerin ortadan kaldırılması adına daha güçlü ve etkili bir adım olmuştur.

Oy kullanma yerlerinin engelli bireyler için daha erişilebilir hale geldiği, önceki dönemlere göre bir iyileșme olduğu da görüşmeciler tarafından kaydedilmiștir. Nitekim bedensel engelli (A13) "oy kullandı̆̆ım binaya giriş rampası yapıldığı için son iki seçimde tekerlekli sandalyemle okula gidip rahatlıkla oyumu kullandım ancak daha önceki seçimlerde binanın durumu uygun olmadı̆̆ı için ruhen ve bedenen çok incindim" diyerek bu konuda yaşanan olumlu gelişmeyi ifade etmiştir. Dolayısıyla oy kullanılan binalar ile yerel yönetim ve hükümet binaları gibi kamu binalarına erişilebilirliğin sağlanması, engelli bireylerin siyasi konulardaki kamusal tartışmalara katılma, diğer bireylere eşit olarak oy kullanma ve katılma hakkını kullanabilmeleri için hayati öneme sahiptir (FRA, 2014, s.48).

Türkiye'de seçimlerin genel çerçevesini belirleyen 1961 tarihli ve 298 sayılı Seçimlerin Temel Hükümleri ve Seçmen Kütükleri Hakkında Kanunun çeşitli maddelerinde engelli, yaşlı ve hasta seçmenlerin seçim sandığına erişmesini sağlayacak çeşitli düzenlemeler bulunmaktadır: Buna göre, "sandıkların konulacağı yerleri ve oy verme işinin vaktinde sona ermesi için gerekli tedbirleri ilçe seçim kurullarının denetiminde sandık kurulu tespit eder. Sandıkların konulacağı yerlerin belirlenmesinde seçmenin oyunu kolaylıkla, serbestçe ve gizli şekilde verebilmesi gözetilir. Engelli seçmenlerin oylarını rahatlıkla kullanabilmeleri için gerekli tedbirler alınır....(m.74) “...0y verme günü sandık başına gelecek seçmenler, sandık kurulu önüne başkan tarafından sıra ile birer birer alınırlar. Gebeler, hastalar ve engelliler bekletilmezler. Yaşlılar önce alınabilirler (m.90)”. “Körler, felçliler veya bu gibi bedeni engellilikleri açıkça belli olanlar, bu seçim çevresi seçmeni olan akrabalarından birinin, akrabası yoksa diğer herhangi bir seçmenin yardımı ile oylarını kullanabilirler. Bir seçmen birden fazla malule refakat edemez... (m.93)." 


\section{B. Seçim Materyalleri ve Erişilebilirlik}

Engelli bireyler açısından bir başka önemli sorun alanı seçim materyallerine ilişkindir. Engelli bireylerin çeşitliliği göz önüne alındığında özellikle görme engelli seçmenler oy kullanma sırasında ciddi zorluklar ile karşılaşmaktadırlar. ABD'de Schur ve Kruse, (2013)'un yaptıkları araştırmaya göre yaklaşık üçte bir engelli seçmen, oy kullanma esnasında sandık görevlilerinin veya aile üyelerinin yardımına ihtiyaç duymaktadırlar. Ayrıca engelli seçmenlerin \%6.5'i oy kullanma sırasında büyüteç, büyük ekran, alçaltılmış makineler gibi çeşitli araçları kullandıklarını da belirtmişlerdir (Schur \& Adya, 2013)

Türkiye'de seçim metaryallerinde erişilebilirliğin sağlanması çerçevesinde ilk kez 24 Haziran 2018 seçimlerinde kullanılmak üzere "Görme engelliler için özel oy pusulası" hazırlanmış ve kullanılmıștır. 24 Haziran 2018 seçimlerinde görme engelli bireylerin bir kısmı önceki seçimlerde olduğu gibi bir yakını veya bir görevlinin yardımı ile oyunu kullanırken, bir kısmı ise ilk defa Braille alfabesine uygun olarak hazırlanan, şablonu kullanarak oyunu yalnız başına kullanmıștır. Daha önceki seçimlerde birçok kez oy kullanmış olan görme engelli (A5) daha önceki seçimlerde kendi başına oy kullanamadığını yardım alarak oy kullandığını belirtmiștir. Ailesinden birilerinin yardımıyla oyunu kullandığını bunun da o kadar kolay olmadığını, sandık görevlilerini "zorlaya zorlaya aileden birileriyle oyumuzu kullandık" sözüyle bu esnada yaşadığı zorluğu dile getirmiştir. 24 Haziran 2018 seçimlerinden önce yaptığımız görüșmede görme engelli (A6) 2002 yılından bu yana tüm genel ve yerel seçimlerde oy kullandığını ve oyunun annesi tarafından kullanıldığını ifade etmiştir: "Annem, ben ve sandık başkanı birlikte kabine giriyoruz, ben söylüyorum annem işaretliyor, sandık başkanı da kontrol ediyor." Bir başka görme engelli (A7) ise yalnızca ailesinden biriyle birlikte kabine girdiğini ve oy kullandığını belirtmiştir: "Ailecek biliyoruz zaten hangi partiye oy vereceğimizi, ağabeyim ona göre oy veriyor, bir sorun olmuyor". Sonradan görme engelli olan (A9) babasıyla birlikte oy kullandığını ve oy kullanma sırasında bir zorluk yaşamadığını fakat sandık görevlilerinin bakışından rahatsız olduğunu ifade etmiştir. Görme engelli (A9) "Gözüm dıştan belli olmadığı için sanki inanmıyorlarmış gibi geliyor bana". Görme engelli (A3) ilk defa bu seçimlerde kendi başına şablon ile oy kullandığını belirtmiştir. Görme engelli (A3) "Benim için anlamı büyük, bana kendimi iyi hissettirdi, özgürlüğü yaşadım” sözleriyle özel olarak hazırlanan şablon ile oy kullanmanın önemini açıkça ifade etmiştir. Yine daha önceki seçimlerde yakınlarından birinin yardımıyla oy kullanan görme engelli (A2) yeni uygulamayla ilgili olarak "benim için tam anlamıyla özgürlük oldu” ifadesini kullanmıștır. Her ne kadar görüștüğümüz görme engelli bireylerin çoğunluğu ailelerinden birinin yardımı ile oy kullanırken siyasal tercihleri açısından kendilerini rahat hissettiklerini, aileleri ile aynı siyasal tercihlere sahip olduklarını belirtseler de örneğin görme engelli (A2) gibi kimi bireyler ailelerinden farklı siyasal tercihlere sahip olduklarını ancak bunu oy kullanma sırasında açıç̧a ifade edemediklerini ve yaşadıkları gerilimi belirtmişlerdir. Diğer taraftan görüşme yapılan görme engellilerden birçoğu yeni uygulamadan haberdar olamadıklarını dolayısıyla, önceki dönemlerde olduğu gibi yine yakınlarının yardımıyla oy kullandıklarını ifade etmişlerdir. Bunun nedeni sorulduğunda örneğin görme engelli (A4) "Braille"i pek 
bilmediğini, bu nedenle hata yapmamak için oyunu kuzeninin yardımıyla kullandığını" belirtmiştir. "Görme engelli (A6) görme engelliler için hazırlanan özel oy pusulası ile oy kullanır mısınız" sorusuna "Aslında annem kullansa daha iyi olur, belki ben hata yaparım oy boşa gider" biçiminde yanıtlamıştır. Görme engelli (A7) de hata yapma korkusu ile kendi başına oy kullanmayı tercih etmeyeceğini ifade etmiştir. Bu araştırmaya katılan katılımcılardan bazıları, özellikle genç kuşaklar arasında "Braille alfabesi" bilme oranının düşük olduğunu da belirtmişlerdir. 24 Haziran 2018 seçimlerinde görme engelliler için Braille alfabesi ile hazırlanan özel oy pusulası, çok önemli bir gelişme olmakla birlikte Braille bilmeyen görme engelliler açısından yararlı olamamıștır. Braille alfabesi bilmeyen görme engelliler için bazı ülkelerde uygulanan, siyasal partilerin, adayların amblemlerinin kabartmalı olarak yer aldığı ve dokunmaya dayalı özel oy pusulaları hazırlanması daha yararlı olabilir.

"Braille alfabesi" bilme oranının genç kuşak arasında düşük düzeyde olmasının nedenleri bașka bir araştırmanın konusu olmakla birlikte kısaca belirtmek gerekirse teknolojik gelişmelerin artmasıyla birlikte görme engelliler için hazırlanan ve daha çok dinlemeye dönük uygulamaların "Braille alfabesi" ile okuma oranını düşürdügü kanısı katılımcılar tarafından dile getirilmiştir. 24 Haziran 2018 seçimlerinden sonra yaptığımız odak grup görüşmesinde, bazı görme engelli katılımcılar, görme engelliler için özel olarak hazırlanan özel oy pusulasından haberdar olmadıklarını ifade etmişlerdir. Örneğin görme engelli (A10) ilçede yaşadığını, derneğe ${ }^{3}$ çok fazla gidemediğini başka iletişim kanallarından da duymadığını bu nedenle haberdar olamadığını söylemiştir. Oysa 24 Haziran 2018 seçimlerinden önce özel oy pusulası dernek başkanı tarafından dernek üyelerine tanıtılmıştır. Görme engelli (A10) gibi dernek merkezine çok fazla gidemeyenler, bu yeni uygulamadan haberdar olamamışlardır. Bu örnek olay engellilere dönük kurulmuş olan derneğin yerine getirdiği işlevleri göstermesi ve diğer yandan özellikle engellilerin bilinçlenmesi, örgütlenmesi açısından sivil toplum alanının geliştirilmesinin önemini ve değerini göstermesi bakımından da son derece anlamlı ve önemlidir.

Seçim materyallerinin geliştirilmesi kapsamında özellikle düşük düzeyde görme engelliler için daha büyük yazı karakterleriyle hazırlanmış özel oy pusulaları hazırlanması oldukça yararlı olabilir. Örneğin görme engelli (A8) kendi başına oy kullandığını ifade etmiş, ancak daha büyük ölçüde hazırlanacak olan pusulalarının ve yönlendirme tabelalarının yararlı olacağını belirtmiştir.

\section{Engellilere Dönük Farklı Oy Kullanma Yöntemleri}

Genel olarak dünyada özel olarak da gelişmiş Kuzey'de nüfusun giderek yaşlanması ile birlikte düşünüldüğünde engelli birey sayısı giderek artmakta ve bu sayının daha da artması beklenmektedir. Örneğin $A B^{\prime}$ de 75 yaş üzerindekilerin üçte birinden fazlası belirli bir ölçüde kendilerini sınırlayan birtakım engellerle yaşamakta \%20'sinden fazlası ise ciddi derecede engelli durumundadır (Avrupa Engellilik Stratejisi 2010-2020, 2010). Hal böyle olunca engelli bireyler giderek büyüyen bir toplumsal

\footnotetext{
${ }^{3}$ Görmeyenler Kültür ve Birleșme Derneği Malatya Şubesi.
} 
grubu oluşturdukları için seçimlere katılımları genel oy kullanma düzeyini önemli ölçüde etkileyebilecek duruma ulaşmış durumdadır. Bazı ülkelerin seçim kanunlarında engellilerin seçimlere katılımını artırmaya dönük özel oy kullanma yöntemleri benimsenmiş ve düzenlenmiştir. Kimi ülkelerde engelli bireylerin oy kullanmasını sağlamak için posta yoluyla oy kullanma ve seçim gününden önce oy kullanma gibi kimi esnek ve özel oy kullanma yöntemleri geliștirilmiștir (Schur \& Adya, 2013). Çeşitli ülke örneklerindeki uygulamalara bakıldığında örneğin, ABD'de engelli bireyler posta yoluyla ve internetten oy kullanabilirken (Pristley vd. 2016, s.1-9), Belçika'da engelli bireyler internetten ve ayrıca engelli bireyler adına vekâletle oy kullanma olanağı bulunmaktadır. Buradaki vekâletle oy kullanma, bir sağlık raporu ile kanıtlanmak kaydıyla hastalık nedeniyle sandık merkezine gitmesi ya da taşınması mümkün olmayan bir kişi, başka bir seçmenin kendi adına oy kullanma yetkisi verebilmesini ifade etmektedir. Bulgaristan'da oy kullanma noktasına gidemeyen engelli bireylere seçim gününden önceki otuz gün içinde başvurmaları halinde, seyyar sandıkla oy kullanma olanağı tanınmıştır. Çekya'da engelli seçmenler için seyyar seçim sandığı uygulaması benimsenmiş, Almanya'da seçmenler, oy kullanma yerine giderek oy kullanmanın yanı sıra, evden, bir bakım kurumundan veya posta yoluyla oy kullanabilmektedirler. Danimarka'da ise seçme hakkına sahip olan tüm seçmenlere posta yoluyla oy kullanma olanağı sağlanmıştır. Ayrıca hastalık veya hareket kabiliyetinden dolayı seçmenler oy verme istasyonuna gidemedikleri durumda, önceden başvuru yapmak kaydıyla kendi evlerinde posta yoluyla oy kullanabilmektedirler (FRA, 2014).

2018 yllına kadar Türkiye'de engelli seçmenlere yönelik alternatif oy kullanma yöntemleri düzenlenmemişti. 2013 yılı sonunda YSK "mobil-seyyar seçim sandıkları" üzerinde çalışma başlattığını duyurmuş fakat bu konuda 24 Haziran 2018 seçimleri öncesine kadar bir gelişme yaşanmamıştı. İlk olarak 24 Haziran 2018 seçimlerinde fiziksel engelli seçmenler için önemli bir yeni uygulama olan "seyyar sandık" hayata geçirilmiştir. Seyyar sandık uygulaması birçok Avrupa Birliği ülkesinde dahi uygulamaya henüz girmemiş, önemli bir gelişme olarak değerlendirilebilir. 298 sayılı Kanunun 14. maddesine yapılan ekleme ile "hastalığı" veya "engeli" sebebiyle "yatağa bağımlı olan" seçmenlerin, engelli beyan formu ile bir yakını aracılığıyla yaptıkları başvuru sonrasında, Yüksek Seçim Kurulunun (YSK) belirlediği kriterlere göre başvurusu kabul edilen seçmenler, "muhtarlık seçimleri hariç olmak" üzere seyyar sandıklarda oy kullanabilecek bunun için seyyar sandık kurulu oluşturulmuştur. Seyyar sandık kurulu bir başkan, altı asıl ve altı yedek üyeden oluşmaktadır. Seyyar sandık kurulu, seçmenlerin adreslerine göre bir güzergah belirleyerek gider. Seçmenin adreste bulunmaması veya makul sürede kapının açılmaması durumunda, bu husus sandık seçmen listesine şerh düşülür ve aynı zamanda tutanak defterine işlenerek imza altına alınır. Bu durumda o seçmenin adresine tekrar gidilmez (Seyyar Sandık Kurullarının Oluşumu ile Görev ve Yetkileri 135/II sayılı genelge m.14).

Son bir yıldan bu yana yatağa bağımlı duruma gelen (A15) seyyar sandık uygulamasını, "çok yerinde bir uygulama, daha önceki seçimlerde zor da olsa sandık başına gitmiștim, ancak bu seçimlerde gidemeyecek duruma geldim. Gerçekten sadece benim için değil, çocuklarım için de büyük kolaylık oldu” sözleriyle seyyar sandık uygulamasından duyduğu memnuniyeti ifade etmiștir. 
Görüşme yaptığımız kişilerden biri olan 92 yaşındaki (A14) bir yere gittiği için sabah saatlerinde evde olamadığından dolayı, seyyar sandık uygulamasına başvuru yapmıș olmasına rağmen oyunu kullanamamıștır. Bu durumu "Sandık görevlileri, sabah çok erken saatlerde eve gelmişler, komşuya tutanak imzalatıp gitmişler, bir daha da gelmediler" sözleriyle ifade etmiștir. Seyyar sandık uygulamasındaki beklenen yararı karşılamak adına bundan sonraki seçimlerde bir öneri olarak belirli bir zaman aralığında seçmenin evine gidileceğinin belirtilmesi daha yararlı olabilir. Ayrıca engelli bireyler için sabahın ilk saatleri değil de günün ortası daha çok tercih edilebilir bir zaman aralığı olabilir.

Seyyar sandık uygulaması hasta, yatağa bağımlı ve bedensel engelli seçmenler açısından önemli bir gelişme olmakla birlikte kimi bedensel engelliler seyyar sandık uygulamasını engelli olmayan diğer seçmenlerle aralarında bir ayrımcılık olarak görmüşlerdir. Nitekim bedensel engelli (A12) seyyar sandık uygulamasına başvurmayanlardan biridir. Neden bașvurmadığı sorulduğunda "benim akülü arabam var kendim gittim, ben o tür şeyleri pek sevmiyorum ayrıca bu tür bir uygulamaya başvurduğumda diğer vatandaşlarla eşit şartlarda olmayacağım algısı oluşacaktı" biçiminde bu konudaki düşüncesini ifade etmiştir.

\section{Sonuç ve Öneriler}

Birleşmiş Milletler Engellilerin Haklarına İlişkin Sözleşme’ye yansıyan sosyal model anlayışı, engelliliği tedavi edilmesi gerekli bir olgu olarak gören egemen söylemleri ve bunların biçimlendirdiği engellilere dönük toplumsal algı ve tutumların değişmesi yanında BM Sözleşmesini imzalayan hükümetlere, engelli bireylere diğer vatandaşlarla aynı hakları garanti etme ve bu hakları korumak bakımından sorumluluk yüklemesi açısından da oldukça önemli bir gelişme olmuştur. Vatandaşlar için seçimlerde oy kullanmak, en temel ve doğrudan gerçekleştirilebilen bir siyasal faaliyet olarak kabul edilmektedir. BM Sözleşmesinde yer alan engelliliğe dayalı ayrımcılığın ortadan kaldırılması bağlamında engelli bireylerin seçimlerde oy kullanmalarının sağlanması, engelli olmayanlarla eşitliğin sağlanması açısından oldukça önemli bir konudur.

Türkiye'de son dönemde Birleşmiş Milletler ve Avrupa Birliği gibi ulus-ötesi kuruluşların da öncülüğünde engelli bireylerin seçimlere katılımları konusunda birtakım olumlu gelişmelerin yaşandığı görülmüștür. Oy kullanma yerlerinin engelli bireyler için daha erişilebilir hale getirilmesi, seçim materyallerinde yaşanan iyileştirmeler bu gelişmeler arasındadır. 24 Haziran 2018 seçimlerinde kullanılmak üzere hazırlanan "Görme engelliler için özel oy pusulası" BM Sözleşmesinde belirtilen "gizli oylama" ilkesinin hayata geçirilmesi bakımından oldukça önemli ve yararlı bir gelişme olmuştur. Oy kullanılan binaların mimari yapılarında iyileștirmelere gidilmesinin yanısıra bedensel engelliler için de seyyar sandık uygulaması bu süreçte başlatılmıştır. Bu sayede engelli bireylerin seçim sandığına "erișilebilirliği" kolaylaștırılmıștır. Bütün bu uygulamaların yanısıra günümüzün insan hakları bağlamında engelli bireylerin tam anlamıyla eşit vatandaşlar haline gelmeleri konusunda, uygulamada devam eden birtakım eksiklikler bulunduğu dikkat çekmektedir. Sandık görevlilerinin damgalayıcı 
bakış ve eylemleri, engelli bireylerin kendilerini eşit vatandaşlar olarak hissetmelerinin önünde duran önemli engellerin başında gelmektedir. Bu durum yalnızca seçimler bağlamında değil, genel olarak birçok kamusal hizmet bakımından uygulamada genel olarak karar verici pozisyonunda bulunan kamu yöneticileri için de geçerli bir durumdur. Dolayısıyla engellilere dönük toplumsal algı ve tutumların eşit vatandaşlık biçiminde dönüşmesi önemli ve gerekli görünmektedir. Sonuç olarak; ülkemizde son dönemde engelli bireylere yönelik birçok alanda iyileşme yaşandığı gibi seçim sürecinde de gerek binaların ulaşılabilirliği gerekse seçim görevlilerinin engelli bireylere ulaşılabilirliği daha da kolaylaştırılmıştır. Bu uygulamalarla, engelli bireylerin seçimlere katılım oranı artırılmaya çalışılmıştır.

\section{KAYNAKÇA}

AKYOL, E. (2016). Siyasal kültür. Kamu politikaları ansiklopesi. (Ed.) H.Altunok, F.G.Gedikkaya, (ss.315-318). Ankara: Nobel.

ALTAN, C. (2011). Eğitim, siyasal eğilim ilişkisi: Mersin örneği. CÜ İktisadi ve İdari Bilimler Dergisi. 12(1). ss.313-329.

Avrupa Engellilik Stratejisi. (2010). 2010-2020.

BEZMEZ, D. YARDIMCI, S. ŞENTÜRK, Y. (2011). Giriș. (Der.)D. Bezmez vd. Sakatlık çalışmaları sosyal bilimlerden bakmak. (ss. 17-25). İstanbul: Koç Üniversitesi Yayınları.

Birleşmiş Milletler (BM) Engellilerin haklarına İlişkin sözleşme (2009).

BURCU, E. (2015). Engellilik sosyolojisi. Ankara: Anı Yayıncılık.

ÇAM, E. (2002). Siyaset bilimine giriş. İstanbul: Der Yayınları.

DRIEDGER, D. (1989). The last civil rights movement: disabled peoples' international. New York: St. Martin's Press.

5378 sayılı Engelliler Hakkında Kanun (EHK)

Engelsiz Türkiye İçin: Yolun Neresindeyiz? (2013). (Yay. Haz.) Elzi Menda vd. Sabancı Üniversitesi Yayınları, 2013.

Türkiye'de Engellilere Yönelik Ayrımcılık Hak İhlalleri 2011 Yılı İzleme Raporu. (2011). Eşit Haklar İçin İzleme Derneği (ESHID). (Yay. Haz.M. Işık vd.), Ankara. EŞHID Yayınları. No:2.

HAGUE, R, HARROP, M.(2017). Siyaset bilimi. (İ. Yıldız. vd., Çev.) Ankara: Dipnot Yayınları.

HUGHES, B. K. (2011). Sakatlık sosyal modeli ve kaybolan beden: bir yeti yitimi sosyolojisine doğru. (Der.) D. Bezmez vd. Sakatlık çalışmaları sosyal bilimlerden bakmak. (ss.63-80). İstanbul: Koç Üniversitesi Yayınları.

FRA (2014). The right to political participation for persons with disabilities: human rights indicators, FRA: European Agency for Fundamental Rights, https://fra.europa.eu/sites/default/files/fra- 2014-right-political-participationpersons-disabilities en.pdf

GÜL, İ.I. KARAN, U. (2011). Ayrımcılık yasağı kavram, hukuk izleme ve belgeleme. (Ed.) B. Yeşiladalı, G. Ayata. İstanbul: İstanbul Bilgi Üniversitesi Yayınları. 
HALL, T. ALVAREZ M.R. (2012). Defining the barriers to political participation for individuals with disabilities". The information technology and innovation foundation: Accessible voting technology initiative. Working Paper No. 001.

International Foundation for Electoral Systems (IFES), (2014). Equal access: how to include persons with disabilities in elections and political processes". IFES and NDI (National Democratic Institute), 209(1), s.3-4. https://doi.org/10.1038/sj.bdj.2010.586.

KIŞLALI, A.T. (2003). Siyasal sistemler. Ankara: İmge Kitabevi, 6.Baskı.

LIPSET, S. M. (1986). Siyasal insan. (M.Tunçay, Çev.) Ankara: V Yayınları.

MATTILA, M. PAPAGEORGIOU, A. (2017). Disability, perceived discrimination and political participation. International Political Science Review, 38(5), s.505-519. https://doi.org/10.1177/0192512116655813

ORUM A. J.Dale (2016). Siyaset sosyolojisi günümüz dünyasında iktidar ve katılım. (I. Kaya, Çev.) İstanbul: Say Yayınları.

PRIESTLEY, M. STICKINGS, M., LOJA, E., GRAMMENOS, S., LAWSON, A., WADDINGTON, L. FRIDRIKSDOTTIR, B. (2016). The political participation of disabled people in Europe: Rights, accessibility and activism. Electoral Studies, 42, s.1-9. https://doi.org/10.1016/j.electstud.2016.01.009

PRINCE, M. J. (2014). Enabling the voter participation of Canadians with disabilities: Reforming Canada's electoral systems. Canadian Journal of Disability Studies. 3(2). s.94-120.

SACKEY, E. (2015). Disability and political participation in Ghana: an alternative perspective. Scandinavian Journal of Disability Research. 17:4. s.366-381. DOI: 10.1080/15017419.2014.941925.

SCHRINER, K., OCHS, L. A., \& SHIELDS, T. G. (1997). The last suffrage movement: Voting rights for persons with cognitive and emotional disabilities, Publius. 27(3). s.7596. https://doi.org/10.1093/oxfordjournals.pubjof.a029929

SCHUR, L. SHIELDS, T. KRUSE, D. SCHRINER, K. (2002). Enabling democracy: disability and voter turnout. Political Research Quarterely. 55(1). s.167-190.

SCHUR, L. (2003). Contending with the 'double handicap': political activism among women with disabilities. Women and Politics, 25(1/2). s.31-62.

SCHUR, L. AMERI, M. \& ADYA,M. (2017). Disability, voter turnout, and polling place accessibility. Social Science Quarterly, 98(5), s.1374-1390.

https://doi.org/10.1111/ssqu.12373

SCHUR, L. ADYA M. (2013). Sidelined or mainstreamed? Political participation and attitudes of people with disabilities in the United States. Social Science Quarterly. 94(3). s.811-839.

SCHUR, L. SHIELDS T. \& SCHRINER K. (2005). Generational cohorts, group membership, and political participation by people with Disabilities. Political Research Quarterly. 58(3), s.487-496.

SCHUR, L. DOUGLAS K. (2000). What determines voter turnout?: Lessons from citizens with disabilities. Social Science Quarterly, 81(2), s.571-587.

Seyyar Sandık Kurullarının Oluşumu ile Görev ve Yetkileri 135/II sayılı Genelge http://www.ysk.gov.tr/doc/genelge/dosya/77638/2018CBMV-Genelge135-2.pdf 
SHAKESPEARE, T. (2011). Sakatlık sosyal modeli. (Der.) D. Bezmez vd. Sakatlık çalışmaları sosyal bilimlerden bakmak. (ss. 51-62). İstanbul: Koç Üniversitesi Yayınları. TURAN, İ. (1977). Siyasal sistem ve siyasal davranış. İstanbul: IÜ İktisat Fakültesi Yayını.

\section{Summary}

Disability is explained in the literature within the framework of two theoretical models. Medical model is described, which is one of these models the disability can explain as an individual's deficiency or disease arising from the individual. According to social model, in the case of making necessary arrangements in society, it is emphasized that people with disabilities can participate in all areas of life. Therefore, the social models improve the dominant social practices and discourses. As a matter of fact, it has been seen that the definition and point of view of disability in various decision and policy documents of supra-national organizations such as the United Nations (UN) and the European Union (EU) have been established within the framework of the social model since the 1970s.

Political participation can be realized in many different dimensions such as following political literature, voting in elections, becoming a member of political parties. Voting in elections is accepted as a kind of political participation that can be realized. Disabled people have a lower level of political participation than others because of their disability (physical, mental, visual etc.). Therefore, disability is crucial of political participation. It is a requirement of modern human rights law, as well as ensuring the high participation of people with disabilities in politics. Although the rate of participation of people with disabilities in general is lower than that of non-disabled individuals, it has been shown that positive developments such as employment status and employment of disabled individuals facilitate the participation of disabled individuals in political life.

The right to political participation of people with disabilities has been organized at the highest level within the framework of international law formed by organizations such as the United Nations Convention on the Rights of Persons with Disabilities (CRPD), the Council of Europe and the European Union. With the publication of the Disabled People Law 5378, which was issued in 2005, an important transformation has started. In line with the UN Convention, the law aims to make buildings, transportation, information and communication technology accessible and accessible to persons with disabilities independently under the title of accessibility. The purpose of this study was to solve the problems in accordance with the research questions: "People with disabilities are living what challenges such as in the process of voting?", "for people with disabilities in Turkey encourages use of the elections means, what are the mechanisms? Are they adequate?" noted in the United Nations Convention on the Rights of Persons with Disabilities. In this study, 15 physically and visually impaired people living in Malatya were conducted before the elections of June 24, 2018 and in April-May 2018 and immediately after the June 24th elections in July 2018. Group meeting was held with various members of the "Association for Blind Culture and Merger" in Malatya. According to the results of the interviews in Turkey under the leadership of the United Nations and transnational organizations such as 
the European Union positive developments on the political participation of persons with disabilities occurred. Improvements were made in the architectural structures of polling place, special ballot papers were prepared for the visually impaired people, and mobile ballot box application was initiated for the physical disabled people. In addition to all these practices, nowadays it has become clear that there are some deficiencies in the way that disabled people become fully equal citizens in terms of the context of human rights. As a result of the study, in addition to the accessibility of the buildings in the election process, the accessibility of the electoral officials to the disabled people has been further facilitated and it has been supported that disabled people should be more active in the political participation process of the disabled people.

\section{EK: Derinlemesine Görüşme Katılımcılar Listesi}

A1: Bedensel engelli, 24 yaş, erkek, çalışmıyor.

A2: Görme engelli, 24 yaș, erkek, kamuda çalışıyor.

A3: Görme engelli, 34 yaş, kadın, kamuda çalışıyor.

A4: Görme engelli, 36 yaş, kadın, çalışmıyor.

A5: Görme engelli, 31 yaş, erkek, kamuda çalışıyor.

A6: Görme engelli, 36 yaş, erkek, çalışmıyor.

A7: Görme engelli, 36 yaşında, kadın, çalıșmıyor.

A8: \%70 oranında görme engelli, 27 yaşında, kadın, özel sektörde çalışıyor.

A9: Görme engelli, 24 yaşında, kadın, çalışmıyor.

A10: Görme engelli, 21 yaşında, kadın, çalışmıyor.

A11: Bedensel engelli, 50 yaşında, erkek, çalışmıyor.

A12: Bedensel engelli, 25 yaşında, kadın, öğrenci, çalışmıyor.

A13: Bedensel engelli, 59 yaşında, kadın, çalışmıyor.

A14: Geriartrik Hasta (yatağa bağımlı), 92 yașında, kadın.

A15: Geriartrik Hasta (yatağa bağımlı), 68 yaşında, erkek. 